\title{
Karakter Hukum Perusahaan Perseroan dan Status Hukum Kekayaan yang Dimilikinya
}

\author{
Ridwan Khairandy \\ Fakultas Hukum Universitas Islam Indonesia Yogyakarta \\ Jl. Tamansiswa No. 158 Yogyakarta \\ ridwan_kharandy@uii.ac.id
}

\begin{abstract}
The legal status of Persero assets causes different interpretation of the definition of state finance in several regulations of law. This research studies: First, legal characters of Persero; second, legal status of Persero assets. This research is normative research referring to legal principles and norms stipulated in the regulations of law. The instruments used to collect the legal materials were literature and document studies. This research concludes that first, Persero is identical with Limited Liability Company. Persero is not public legal entity but private legal entity subject to private law. Second, all assets of a Persero belong to the Persero instead of state. State asset in the Persero is the shares owned.
\end{abstract}

Key words: Legal characters, legal status of Persero, state finance

\begin{abstract}
Abstrak
Status hukum aset Persero menimbulkan perbedaan penafsiran terkait dengan makna keuangan negara dalam beberapa peraturan perundang-undangan. Penelitian ini mengkaji permasalahan: pertama, karakter hukum Persero; kedua, status hukum kekayaan Persero. Penelitian ini adalah penelitian normatif karena mengacu kepada asas-asas hukum dan norma-norma hukum yang terdapat dalam peraturan perundang-undangan. Instrumen yang digunakan untuk mengumpulkan bahanbahan hukum berupa studi kepustakaan dan studi dokumen. Penelitian ini menyimpulkan pertama, Persero identik dengan perseroan terbatas. Persero bukan badan hukum publik, tetapi badan hukum privat yang tunduk kepada hukum privat; Kedua, kekayaan keseluruhan yang pada Persero adalah milik Persero itu sendiri bukan milik negara. Kekayaan negara di dalam Persero adalah saham yang dimilikinya.
\end{abstract}

Kata Kunci : Karakter hukum, status hukum Persero, keuangan negara. 


\section{Pendahuluan}

Dalam rangka untuk memberikan sumbangan bagi perkembangan perekonomian nasional pada umumnya dan penerimaan negara pada khususnya, negara Republik Indonesia mendirikan badan usaha milik negara (BUMN) yang tujuannya mengejar keuntungan. Bentuk BUMN dimaksud adalah perusahaan perseroan (Persero). Perseroan ini menurut Pasal 1 angka 1 Undang-Undang Nomor 19 Tahun 2003 (selanjutnya disebut UU No. 19 Tahun 2003) adalah BUMN berbentuk perseroan terbatas (PT). Karena Persero berbentuk PT, maka Persero adalah badan hukum privat, bukan badan hukum publik.

Karena Persero merupakan perseroan terbatas, maka Persero harus tunduk kepada konsekuensi hukum yang melekat pada prinsip-prinsip hukum perseroan terbatas dan ketentuan hukum mengenai perseroan terbatas sebagaimana diatur di dalam Undang-Undang Nomor 40 Tahun 2007 tentang Perseroan Terbatas (selanjutnya disebut UU No. 40 Tahun 2007).

Konsekuensi hukum yang paling mendasar dalam perseroan terbatas sebagai badan hukum adalah adanya pemisahan kekayaan. Modal perseroan terbatas yang berasal dari pemegang saham adalah kekayaan yang telah dipisahkan dari kekayaan pribadi pemegang saham. Dengan adanya pemisahan kekayaan tersebut, maka segala kekayaan yang dimiliki perseroan terbatas bukan milik pemegang saham lagi, tetapi menjadi kekayaan perseroan terbatas.

Hal tersebut telah dinyatakan tegas oleh Pasal 1 UU No. 19 Tahun 2003 menentukan bahwa BUMN adalah badan usaha yang seluruh atau sebagian besar modalnya dimiliki oleh negara melalui penyertaan modal secara langsung yang berasal kekayaan negara yang dipisahkan.

Makna frase yang berkaitan dengan "kekayaan negara yang dipisahkan" menjadi rancu, bahkan terjadi konflik norma UU No. 40 tahun 2007 dan UU No. 19 tahun 2003 dengan UU No. 20 Tahun 2001 tentang Perubahan UU No. 31 Tahun 1999 tentang Tindak Pidana Korupsi, UU No. 17 Tahun 2003 tentang Keuangan Negara, dan PP No. 14 Tahun 2005 jo PP No. 33 Tahun 2006 tentang Tata Cara Penghapusan Piutang Negara/Daerah.

Untuk dapat memahami persoalan makna kekayaan yang dipisahkan dalam Persero dengan baik, harus diteliti atau dikaji secara mendalam mengenai karakter hukum yang melekat pada Persero. 


\section{Rumusan Masalah}

Permasalahan dalam penelitian ini adalah; Pertama, apakah yang menjadi karakter hukum Perusahaan Perseroan? Kedua, bagaimana status hukum kekayaan Perusahaan Perseroan?

\section{Tujuan Penelitian}

Penelitian ini bertujuan: Pertama, untuk mendapatkan pemahaman yang mendalam mengenai karakter hukum Perusahaan Perseroan; dan kedua, untuk mendapatkan pemahaman yang mendalam mengenai status hukum kekayaan Perusahaan Perseroan.

\section{Metode Penelitian}

Penelitian ini adalah penelitian normatif atau penelitian yang mengacu kepada asas-asas hukum dan norma-norma hukum yang terdapat dalam peraturan perundang-undangan dan doktrin. Oleh karena penelitian sangat mementingkan kedalaman terhadap permasalahan yang ada, maka metode penelitian yang dipakai adalah penelitian kualitatif. Bahan-bahan hukum yang diperlukan dalam penelitian ini terditi atas: (1). Bahan Hukum Primer, yang mencakup: (a). Undang-Undang Nomor 19 Tahun 2003 tentang Badan Usaha Milik Negara; (b). Undang-Undang Nomor 40 Tahun 2007 tentang Perseroan Terbatas; (c). UU No. 20 Tahun 2001 tentang Perubahan UU No. 31 Tahun 1999 tentang Tindak Pidana Korupsi; (d). UU No. 17 Tahun 2003 tentang Keuangan Negara; (e). PP No. 14 Tahun 2005 jo PP No. 33 Tahun 2006 tentang Tata Cara Penghapusan Piutang Negara/Daerah. (2). Bahan Hukum Sekunder, yang mencakup: (a). Disertasi; dan (c). Buku.

Alat yang digunakan untuk mengumpulkan bahan-bahan hukum di atas berupa studi kepustakaan dan studi dokumen. Bahan-bahan hukum tersebut dianalisis secara kualitatif dengan menggunakan silogisme hukum. Dalam menerapkan silogisme tersebut teori atau asas-asas dari konsep badan hukum ditempatkan sebagai premis mayor, kemudian peraturan perundang-undangan yang terkait ditempatkan sebagai premis minor. 


\section{Hasil Penelitian dan Pembahasan}

\section{Karakter Hukum Perusahaan Perseroan}

Menurut Pasal 1 UU No. 19 Tahun 2003, BUMN adalah badan usaha yang seluruh atau sebagian besar modalnya dimiliki oleh negara melalui penyertaan secara langsung yang berasal dari kekayaan negara yang dipisahkan.

Dari definisi di atas dapat ditarik kesimpulan, ada beberapa unsur yang menjadi suatu perusahaan dapat dikategorikan sebagai BUMN: 1. badan usaha; 2. modal badan usaha tersebut seluruhnya atau sebagian besar dimiliki oleh negara; 3 . di dalam usaha tersebut, negara melakukan penyertaan secara langsung; 4. modal penyertaan tersebut berasal dari kekayaan negara yang dipisahkan.

\section{Badan Usaha}

Menurut Pemerintah Belanda ketika membacakan Memorie van Toelichting (Penjelasan) Rencana Undang-Undang Wetboek van Koophandel di muka parlemen menyebutkan, bahwa perusahaan adalah keseluruhan perbuatan yang dilakukan secara terus menerus, dengan terang-terangan dalam kedudukan tertentu, dan untuk mencari laba bagi dirinya sendiri. ${ }^{1}$

Menurut Molengraaf, perusahaan adalah keseluruhan perbuatan yang dilakukan secara terus menerus, bertindak ke luar untuk mendapatkan penghasilan, dengan cara memperniagakan barang-barang atau mengadakan perjanjian perdagangan. ${ }^{2}$ Polak berpendapat bahwa, baru ada perusahaan jika diperlukan adanya perhitungan laba-rugi yang dapat diperkirakan dan segala sesuatu dicatat dalam pembukuan. ${ }^{3}$

Perkembangan pengertian perusahaan dapat dijumpai dalam UU No. 3 Tahun 1992 tentang Wajib Daftar Perusahaan, dan UU No. 8 Tahun 1997 tentang Dokumen Perusahaan. Menurut Pasal 1 Huruf b UU No. 3 Tahun 1982, perusahaan adalah setiap bentuk usaha yang bersifat tetap dan terus menerus dan didirikan, bekerja serta berkedudukan dalam wilayah Republik Indonesia untuk tujuan memperoleh keuntungan atau laba. Pasal 1 Butir 2 UU No. 8 Tahun 1997 mendefinisikan perusahaan sebagai bentuk usaha yang melakukan kegiatan secara tetap dan terus

\footnotetext{
${ }^{1}$ Ridwan Khairandy, Pengantar Hukum Dagang, FH UII Press, Yogyakarta, 2006, hlm. 8.

${ }^{2}$ Ibid.

${ }^{3}$ Ibid.
} 
menerus dengan tujuan memperoleh keuntungan dan atau laba baik yang diselenggarakan oleh orang perseorangan maupun badan usaha yang berbentuk badan hukum atau bukan badan hukum, yang didirikan dan berkedudukan dalam wilayah negara Republik Indonesia.

Jika makna perusahaan tersebut mengacu kepada kegiatan yang tujuan akhirnya mencari keuntungan, badan usaha adalah wadah atau organisasi bisnis untuk mengelola atau melaksanakan kegiatan yang bermaksud mencari keuntungan tersebut. Jadi, BUMN adalah organisasi bisnis yang bertujuan untuk mengelola bisnis.

\section{Seluruh atau Sebagian Besar Modalnya Dimiliki oleh Negara}

Jika modal tersebut tidak seluruhnya dikuasai negara, maka agar tetap dikategorikan sebagai BUMN, maka negara minimum menguasai $51 \%$ modal tersebut. Jika penyertaan modal negara Republik Indonesia di suatu badan usaha kurang dari 51\%, tidak dapat disebut BUMN. Misalnya penyertaan negara Republik Indonesia di PT Freeport Indonesia hanya sebesar $5 \%$ dari keseluruhan saham yang ada. Walaupun ada saham negara Republik Indonesia di Freeport Indonesia, perseroan tersebut tetap perusahaan swasta nasional, bukan BUMN. Demikian juga dengan PT Indosat Tbk tidak dapat dikategorikan sebagai BUMN karena kepemilikan saham negara Republik Indonesia di perseroan tersebut hanya sebesar 14,5\%. Qatar Telekom menguasai 40, 77\% saham dan publik sebesar 44,05\% saham.

\section{Penyertaan Secara Langsung}

Mengingat di sini ada penyertaan langsung, maka negara terlibat dalam menanggung risiko untung dan ruginya perusahaan. Menurut Penjelasan Pasal 4 ayat (3) UU No. 19 Tahun 2003, pemisahan kekayaan negara untuk dijadikan penyertaan modal negara ke dalam BUMN hanya dapat dilakukan dengan cara penyertaan langsung negara ke BUMN, sehingga setiap penyertaan tersebut harus ditetapkan dengan Peraturan Pemerintah (PP).

PT Garuda Indonesia Tbk adalah BUMN karena sebagian modal perseroan tersebut berasal dari modal penyertaan langsung di negara Republik Indonesia, tetapi PT Garuda Maintenance Facilities Aero Asia tidak dapat dikategorikan sebagai BUMN, karena modal penyertaannya berasal dari PT Garuda Indonesia Tbk. Perseroan tersebut adalah anak perusahaan PT Garuda Indonesia Tbk. Demikian juga dengan PT Pupuk Kalimantan Timur, perseroan ini adalah perusahaan PT Pusri. Tidak penyertaan langsung di perseroan ini. 


\section{Modal Penyertaan Berasal dari Kekayaan Negara yang Dipisahkan}

Kekayaan yang dipisahkan di sini adalah pemisahan kekayaan negara dari Anggaran Pendapatan dan Belanja Negara (APBN) untuk dijadikan penyertaan modal negara pada BUMN untuk dijadikan modal BUMN. Setelah itu pembinaan dan pengelolaannya tidak lagi didasarkan pada sistem APBN, namun pembinaan dan pengelolaannya pada prinsip-prinsip perusahaan yang sehat. ${ }^{4}$

Melalui pemisahan ini, maka begitu negara melakukan penyertaan di perusahaan tersebut, menjadi kekayaan badan usaha. Penyertaan modal negara dalam rangka pendirian atau penyertaan pada BUMN menurut Pasal 4 jo Penjelasan Pasal 4 ayat (2) huruf b UU No. 19 Tahun 2003, bersumber dari: a. Anggaran Pendapatan dan Belanja Negara; b. termasuk dalam APBN yaitu meliputi proyekproyek APBN yang dikelola oleh BUMN dan/atau piutang negara pada BUMN yang dijadikan sebagai penyertaan modal; c. kapitalisasi cadangan, kapitalisasi cadangan ini adalah penambahan modal disetor yang berasal dari cadangan; d. sumber lainnya, termasuk dalam kategori sumber lainnya ini antara lain keuntungan revaluasi aset.

Tujuan didirikannya BUMN dapat dilihat dari Pasal 2 ayat (1) UU No. 19 Tahun 2003 menentukan bahwa maksud dan tujuan didirikannya BUMN adalah: a. memberikan sumbangan bagi perkembangan perekonomian nasional pada umumnya dan penerimaan negara pada khususnya, di sini BUMN diharapkan dapat meningkatkan mutu pelayanan pada masyarakat sekaligus memberikan konstribusi dalam meningkatkan pertumbuhan ekonomi nasional dan membantu penerimaan keuangan negara; b. mengejar keuntungan. Menurut Penjelasan Pasal 1 ayat (1) huruf a UU No. 19 tahun 2003, meskipun maksud dan tujuan Persero adalah untuk mengejar keuntungan, namun dalam hal-hal tertentu untuk melakukan pelayanan umum, Persero dapat diberikan tugas khusus dengan memperhatikan prinsipprinsip pengelolaan perusahaan yang sehat. Dengan demikian, penugasan pemerintah harus disertai dengan pembiayaannya (kompensasi) berdasarkan perhitungan bisnis atau komersial, sedangkan untuk Perum yang tujuannya menyediakan barang dan jasa untuk kepentingan umum, dalam pelaksanaannya harus memperhatikan prinsip-prinsip pengelolaan perusahaan yang baik; c. menyelenggarakan kemanfaatan umum berupa penyediaan barang dan/atau jasa yang bermutu tinggi dan memadai bagi pemenuhan hajat hidup orang banyak.

${ }^{4}$ Perhatikan Penjelasan Pasal 4 ayat (1) UU No. 19 Tahun 2003. 
Dengan maksud dan tujuan seperti ini, setiap usaha BUMN, baik barang maupun jasa, dapat memenuhi kebutuhan masyarakat; $d$. menjadi perintis kegiatan-kegiatan yang belum dapat dilaksanakan oleh sektor swasta dan koperasi; dan turut aktif memberikan bimbingan dan bantuan kepada pengusaha golongan ekonomi lemah, koperasi, dan masyarakat.

Menurut Penjelasan Pasal 1 ayat (1) huruf d UU No. 19 tahun 2003, kegiatan perintisan merupakan suatu kegiatan usaha untuk menyediakan barang dan/atau jasa yang dibutuhkan oleh masyarakat, namun kegiatan tersebut belum dapat dilakukan oleh swasta dan koperasi karena secara komersial tidak menguntungkan. Oleh karena itu, tugas tersebut dapat dilakukan melalui penugasan kepada BUMN.

Dalam hal adanya kebutuhan masyarakat luas yang mendesak, pemerintah dapat pula menugasi suatu BUMN yang mempunyai fungsi pelayanan kemanfaatan umum untuk melaksanakan program kemitraan dengan pengusaha golongan ekonomi lemah.

Mengenai pengertian Persero ditemukan dalam Pasal 1 Angka 1 UU No. 19 Tahun 2003. Pasal ini mendefenisikan Persero adalah BUMN yang berbentuk perseroan terbatas yang modalnya terbagi dalam saham yang seluruhnya atau paling sedikit 51 \% (lima puluh satu persen) sahamnya dimiliki negara Republik Indonesia yang tujuannya mengejar keuntungan.

Berdasarkan definisi atas, dapat ditarik unsur-unsur yang melekat di dalam Persero, yakni: a. Persero adalah badan usaha; b. Persero adalah Perseroan Terbatas; c. modalnya terbagi dalam saham; d. tujuan didirikannya Persero adalah untuk mengejar keuntungan.

\section{Perusahaan Perseroan adalah Perseroan Terbatas}

Pasal 1 Angka 1 UU No. 19 Tahun 2003 dengan tegas mengidentikkan Persero dengan perseroan terbatas. Untuk mendapatkan yang lebih baik tentang perusahaan perseroan ini harus dilihat apa makna perseroan terbatas tersebut.

Istilah Perseroan Terbatas terdiri dari dua kata, yakni perseroan dan terbatas. Perseroan merujuk kepada modal PT yang terdiri dari sero-sero atau saham-saham. Kata terbatas merujuk kepada tanggung jawab pemegang saham yang luasnya hanya terbatas pada nilai nominal semua saham yang dimilikinya. ${ }^{5}$

${ }^{5}$ H.M.N Purwosutjipto, Pengertian Pokok Hukum Dagang Indonesia, Jilid 2, Djambatan, Jakarta, 1982, hlm. 85. 
Dasar pemikiran bahwa modal PT itu terdiri atas sero-sero atau saham-saham dapat ditelusuri dari ketentuan Pasal 1 angka 1 UU No. 40 Tahun 2007. Pasal tersebut menentukan bahwa "Perseroan Terbatas yang selanjutnya disebut perseroan adalah badan hukum yang merupakan persekutuan modal, didirikan berdasarkan perjanjian, melakukan kegiatan usaha dengan modal dasar yang seluruhnya terbagi dalam saham dan memenuhi persyaratan yang ditetapkan dalam undang-undang ini serta peraturan pelaksanaannya".

Penunjukkan terbatasnya tanggung jawab pemegang saham tersebut dapat dilihat dari Pasal 3 UU No. 40 Tahun 2007 yang menentukan, bahwa pemegang saham perseroan tidak bertanggungjawab secara pribadi atas perikatan yang dibuat atas nama perseroan dan tidak bertanggungjawab atas kerugian perseroan melebihi nilai saham yang telah dimilikinya".

Definisi otentik PT ditemukan dalam Pasal 1 angka 1 UU No. 40 Tahun 2007. Pasal ini menyebutkan bahwa PT merupakan badan hukum yang merupakan persekutuan modal, yang didirikan berdasarkan perjanjian, melakukan kegiatan usaha dengan modal dasar yang seluruhnya terbagi dalam saham. Dari definisi itu dapat ditarik unsur-unsur yang melekat pada PT, yakni: 1. PT adalah badan hukum; 2. PT adalah persekutuan modal; 3. Didirikan berdasarkan perjanjian; 4. Melakukan kegiatan usaha; 5. Modalnya terdiri dari saham-saham.

\section{Perseroan Terbatas Merupakan Badan Hukum}

Pada dasarnya badan hukum adalah suatu badan yang dapat memiliki hakhak dan kewajiban-kewajiban untuk melakukan suatu perbuatan seperti manusia, memiliki kekayaan sendiri, dan digugat dan menggugat di depan pengadilan. ${ }^{6}$

Nindyo Pramono ${ }^{7}$ menyatakan bahwa filosofi pendirian badan hukum adalah bahwa dengan kematian pendirinya, harta kekayaan badan hukum tersebut diharapkan masih dapat bermanfaat bagi orang lain. Oleh karena itu, hukum menciptakan suatu kreasi "sesuatu" yang oleh hukum kemudian dianggap atau diakui sebagai subjek mandiri seperti halnya orang (natuurlijk persoon atau natural person). Kemudian "sesuatu" itu oleh ilmu hukum disebut sebagai badan hukum (rechtspersoon atau legal person). Agar badan hukum itu dapat bertindak seperti halnya

\footnotetext{
${ }^{6}$ Chidir Ali, Badan Hukum, Alumni, Bandung,1987, hlm. 19.

${ }^{7}$ Nindyo Pramono, "Kekayaan Negara Yang Dipisahkan Menurut UU No. 19 Tahun 2003 tentang BUMN”, dalam Sri Rejeki Hartono, et.al, ed, Permasalaban Seputar Hukum Bisnis: Persembahan kepada Sang Maha Guru, Tanpa Penerbit, Yogyakarta 2006, hlm. 142.
} 
orang alamiah, maka diperlukan organ sebagai alat bagi badan hukum itu untuk menjalin hubungan hukum dengan pihak ketiga.

Di dalam hukum, istilah person (orang) mencakup makhluk pribadi, yakni manusia (natuurlijk persoon) dan badan hukum (persona moralis, legal person, legal entity, rechtspersoon). Keduanya adalah subjek hukum, sehingga keduanya adalah penyandang hak dan kewajiban hukum. Dengan perkataan lain, sebagaimana yang dikatakan oleh J. Satrio, mereka memiliki hak/dan atau kewajiban yang diakui hukum. ${ }^{8}$

Oleh karena badan hukum adalah subjek, maka ia merupakan badan yang independen atau mandiri dari pendiri, anggota, atau penanam modal badan tersebut. Badan ini dapat melakukan kegiatan bisnis atas nama dirinya sendirinya seperti manusia. Bisnis yang dijalankan, kekayaan yang dikuasai, kontrak yang dibuat semua atas nama itu sendiri. Badan ini seperti halnya manusia memiliki kewajiban-kewajiban hukum, seperti membayar pajak dan mengajukan izin kegiatan bisnis atas nama dirinya sendiri. ${ }^{9}$

Konsep perusahaan sebagai badan yang hukum yang kekayaannya terpisah dari para pemegang sahamnya merupakan sifat yang dianggap penting bagi status korporasi sebagai suatu badan hukum yang membedakan dengan bentuk-bentuk perusahaan yang lain. Sifat terbatasnya tanggung jawab secara singkat merupakan pernyataan dari prinsip bahwa pemegang saham tidak bertanggungjawab secara pribadi atas kewajiban perusahaan sebagai badan hukum yang kekayaannya terpisah dari pemegang sahamnya. Prinsip "continuity of existence" menegaskan tentang pemisahan kekayaan korporasi dengan pemiliknya. Badan hukum itu sendiri tidak dipengaruhi oleh kematian ataupun pailitnya pemegang saham. Badan hukum juga tidak dipengaruhi oleh perubahan struktur kepemilikan perusahaan. Sebagai akibatnya, saham-saham perusahaan diperdagangkan secara bebas. ${ }^{10}$

Perseroan terbatas sebagai korporasi (corporation), yakni perkumpulan yang berbadan hukum memiliki beberapa ciri substantif yang melekat pada dirinya, yakni: ${ }^{11}$ a. Terbatasnya Tanggung Jawab. Pada dasarnya, para pendiri atau pemegang saham atau anggota suatu korporasi tidak bertanggungjawab secara

${ }^{8}$ J. Satrio, Hukum Pribadi, Bagian I Persoon Alamiah, Citra Aditya Bakti, Bandung, 1999, hlm. 13.

${ }^{9}$ Robert W. Hamilton, The Law of Corporation, Minn West Publishing Co, St. Paul, 1996, hlm. 1.

${ }^{10}$ Erik P.M. Vermuelen, The Evolution of Legal Business Forms in Europe and the United States: Venture Capital, Joint Venture, and Partnership Structures, Kluwer Law International, Deventer, 2002, hlm. 189.

${ }^{11}$ Perhatikan David Kelly, et.al, Business Law, Cavendish Publishing Limited, London, 2002, hlm. 343 - 345. 
pribadi terhadap kerugian atau utang korporasi. Tanggung jawab pemegang saham hanya sebatas jumlah maksimum nominal saham yang ia kuasai. Selebihnya, ia tidak bertanggungjawab; b. Perpetual Succession. Sebagai sebuah korporasi yang eksis atas haknya sendiri, perubahan keanggotaan tidak memiliki akibat atas status atau eksistensinya. Bahkan, dalam konteks PT, pemegang saham dapat mengalihkan saham yang ia miliki kepada pihak ketiga. Pengalihan tidak menimbulkan masalah kelangsungan perseroan yang bersangkutan. Bahkan, bagi PT yang masuk dalam kategori PT Terbuka dan sahamnya terdaftar di suatu bursa efek (listed), terdapat kebebasan untuk mengalihkan saham tersebut; c. Memiliki Kekayaan Sendiri. Semua kekayaan yang ada dimiliki oleh badan itu sendiri. Kekayaan tidak dimiliki oleh pemilik oleh anggota atau pemegang saham. Ini adalah suatu kelebihan utama badan hukum. Dengan demikian, kepemilikan kekayaan tidak didasarkan pada anggota atau pemegang saham; d. Memiliki Kewenangan Kontraktual serta Dapat Menuntut dan Dapat Dituntut atas Nama Dirinya Sendiri. Badan hukum sebagai subjek hukum diperlakukan seperti manusia yang memiliki kewenangan kontraktual. Badan itu dapat mengadakan hubungan kontraktual atas nama dirinya sendiri. Sebagai subjek hukum, badan hukum dapat dituntut dan menuntut di hadapan pengadilan.

Reiner R. Kraakman, menyebutkan bahwa suatu korporasi biasanya memiliki 5 (lima) karakteristik yang penting, yaitu mempunyai personalitas hukum, terbatasnya tanggung jawab, adanya saham yang dapat dialihkan, manajemen terpusat di bawah struktur dewan direksi, dan kepemilikan saham oleh penanam modal. Setiap korporasi pada umumnya didirikan berdasarkan undang-undang yang mencakup 5 (lima) karakteristik tersebut kecuali jika pendiri korporasi tersebut (dan diperbolehkan oleh undang-undang) membuat aturan khusus tersendiri yang meniadakan salah satu dari karakteristik tersebut di atas. ${ }^{12}$

\section{Perseroan Terbatas Merupakan Persekutuan Modal}

Penegasan PT adalah badan hukum yang merupakan persekutuan modal merupakan penegasan bahwa PT tidak mementingkan sifat kepribadian para pemegang saham yang ada di dalamnya. Penegasan ini ditujukan pula untuk membedakan secara jelas substansi atau sifat badan usaha PT dibandingkan dengan badan usaha lainnya, seperti persekutuan perdata.

${ }^{12}$ Reiner R. Kraakman, et.al, The Anatomy of Corporate Law: A Comparative and Functional Approach, Oxford University Press, Oxford, 2005, hlm. 5 
Persekutuan perdata, termasuk firma dan persekutuan komanditer terdiri atas dua orang atau lebih yang masing-masing saling mengenal secara pribadi, misalnya antar saudara atau sahabat karib. Meskipun di dalam persekutuan ada peraturan tentang keluar masuknya sekutu, tetapi tidak boleh mengurangi sifat kepribadian pada persekutuan tersebut. Lain halnya dengan keadaan dalam PT, tujuan utamanya adalah penumpukan modal sebanyak-banyaknya dalam batas waktu yang telah ditentukan dalam anggaran dasar. Bagi PT pada umumnya tidak peduli siapa yang akan memasukkan modalnya dalam perseroan, mereka dapat saja saling tidak dikenal. Jadi, dalam PT ini tidak terdapat sifat kepribadian. ${ }^{13}$

Dalam kenyataannya, tidak semua PT bertujuan untuk menghimpun dana semata (persekutuan atau asosiasi modal) dan mengabaikan sifat kepribadian atau hubungan pribadi pemegang saham. PT dapat diklasifikasikan menjadi dua macam PT, yakni Tertutup dan PT Terbuka atau PT Publik. Di dalam PT Tertutup hubungan pribadi para pemegang saham masih diutamakan. Mereka saling mengenal secara dekat dan tidak banyak jumlahnya. Pemegang saham PT semacam seringkali berasal dari anggota keluarga atau sahabat karib sendiri sehinga seringkali pula PT semacam ini disebut PT keluarga. Ini berlainan kondisinya dengan PT terbuka atau PT publik. Di sini yang diutamakan untuk menghimpun modal sebanyak mungkin dan mengabaikan hubungan pribadi para pemegang saham. Mereka dapat saja saling tidak mengenal satu dengan yang lain. Bagi PT yang melakukan penawaran umum di pasar modal, jumlah para pemegang saham ratusan orang baik orang pribadi maupun badan hukum, baik dari dalam negeri maupun luar negeri.

\section{Perseroan Terbatas sebagai Badan Hukum Didirikan Berdasarkan Perjanjian}

Pasal 1 angka 1 UPPT dengan tegas menyatakan bahwa PT adalah badan hukum yang didirikan berdasarkan perjanjian. Ketentuan ini berimplikasi bahwa pendirian PT harus memenuhi ketentuan-ketentuan yang diatur dalam hukum perjanjian. Jadi, dalam pendirian PT, selain tunduk kepada UUPT, tunduk pula pada hukum perjanjian.

\section{Perseroan Terbatas Melakukan Kegiatan Usaha}

Mengingat PT adalah persekutuan modal, maka tujuan PT adalah mendapat keuntungan atau keuntungan untuk dirinya sendiri. Untuk mencapai tujuan itu, PT harus melakukan kegiatan usaha. Kegiatan usaha itu sendiri harus bertujuan untuk mengejar keuntungan.

\footnotetext{
${ }^{13}$ H.M.N. Purwosutjipto, Op.Cit., hlm. 17.
} 


\section{Modal Dasarnya terdiri atas Saham}

Agar badan hukum dapat berinteraksi dalam pergaulan hukum seperti membuat perjanjian, melakukan kegiatan usaha tertentu diperlukan modal. Modal awal badan hukum itu berasal dari kekayaan pendiri yang dipisahkan. Modal awal itu menjadi kekayaan badan hukum, terlepas dari kekayaan pendiri. Oleh karena itu, salah satu ciri utama suatu badan hukum seperti PT (termasuk PT Persero) adalah kekayaan yang terpisah itu, yaitu kekayaan terpisah dari kekayaan pribadi pendiri badan hukum itu. ${ }^{14}$

Pasal 31 ayat (1) UUPT menyebutkan bahwa modal perseroan terdiri seluruh nilai nominal saham. Modal dasar (maatschappelijk kapitaal atau authorized capital atau nominal capital) merupakan keseluruhan nilai nominal saham yang ada dalam perseroan.

Pasal 32 ayat (2) UUPT menentukan, bahwa modal dasar perseroan paling sedikit sejumlah Rp. 50. 000.000.000,00 (lima puluh juta rupiah). Namun, Pasal 32 ayat (2) UUPT menentukan pula bahwa untuk bidang usaha tertentu berdasarkan undang-undang atau peraturan pelaksanaan yang usaha tertentu tersebut, jumlah minimum modal perseroan dapat diatur berbeda. Misalnya pengaturan jumlah modal bagi perusahaan-perusahaan yang berkaitan dengan kegiatan pasar modal diatur berdasar UU No. 8 Tahun 1995 jo PP No. 45 Tahun 1995. Penentuan jumlah modal minimum jauh lebih tinggi daripada yang ditentukan Pasal 25 ayat (1) UUPT.

Besarnya jumlah modal dasar perseroan itu tidaklah menggambarkan kekuatan finansial riil perseroan, tetapi hanya menentukan jumlah maksimum modal dan saham yang dapat diterbitkan perseroan. Jika perseroan akan menambah modal yang melebihi jumlah modal tersebut, perseroan harus mengubah anggaran dasar. Perubahan anggaran dasar tersebut harus diputus RUPS.

Besarnya jumlah modal dasar itu disebutkan secara tegas dalam akta pendirian perseroan atau anggaran perseroan. Misalnya ditentukan modal perseroan adalah sejumlah “Rp.250.000.000.000,00 terbagi atas 250.000.000,00 saham, masing-masing saham bernilai nominal sejumlah Rp. 1.000,00." Contoh riil modal dasar perusahaan perseroan dapat dilihat dari anggaran dasar PT Telekomunikasi Indonesia (Persero). Pasal 4 anggaran dasar perseroan tersebut menyebutkan: "Modal dasar perseroan berjumlah Rp. 20.000.000.000.000,00 (Dua puluh triliun rupiah) terbagi atas 400.000.000.000 (Empat ratus milyar) saham yang terdiri dari 1 (satu) saham Seri A Dwiwarna dan 39.999.999.999 (Tiga puluh sembilan milyar sembilan ratus sembilan

\footnotetext{
${ }^{14}$ Nindyo Pramono, Loc.Cit.
} 
puluh sembilan juta sembilan ratus sembilan puluh sembilan ribu sembilan ratus sembilan puluh sembilan) saham seri B, tiap-tiap saham dengan nilai nominal Rp. 500,00 (lima ratus rupiah).

Melalui penjelasan di atas dan dengan mengingat unsur yang dikandung makna perusahaan perseroan dapat disimpulkan bahwa BUMN yang berbentuk Persero bukanlah badan hukum tersendiri. BUMN yang berbentuk Persero adalah perseroan terbatas. Oleh karena itu, Persero bukanlah badan hukum publik, tetapi adalah badan hukum privat.

\section{Status Hukum Kekayaan Negara dalam Perusahaan Perseroan}

Oleh karena Persero adalah badan hukum, ia adalah subjek hukum bukan objek hukum. Salah besar jika ada orang menyatakan bahwa PT Pertamina atau Persero lainnya adalah milik negara. Badan hukum adalah subjek hukum, yakni penyandang hak dan kewajiban. Oleh karenanya tidak ada seorang pun yang memiliki Persero tersebut, termasuk negara. Badan itu adalah dirinya sendiri.

Kewajiban pemegang saham di dalam perseroan adalah memasukkan modal. Begitu modal tersebut masuk ke dalam perseroan pada saat yang sama modal tersebut menjadi kekayaan perseroan, bukan lagi kekayaan pribadi pemegang saham, dan kekayaan itu terpisah dari kekayaan pribadi pemegang saham. Apabila penyetoran modal tersebut tidak uang, misalnya tanah yang kemudian dikonversi menjadi saham, tanah harus dilakukan balik nama dari pemegang saham ke perseroan.

Pasal 4 ayat (1) UU 19 Tahun 2003 menyebutkan bahwa modal Persero berasal dari kekayaan negara yang dipisahkan. Modal tersebut dalam konteks hukum perseroan adalah modal penyertaan.

Dalam konsep hukum publik, khususnya hukum administrasi negara, penyertaan modal adalah pemisahan kekayaan negara. Untuk itu diperlukan prosedur administrasi sesuai dengan aturan-aturan pengelolaan kekayaan negara. Berdasarkan ketentuan Pasal 1 angka 7 PP No. 44 Tahun 2005 tentang Tata Cara Penyertaan dan Penatausahaan Modal Negara pada BUMN dan Perseroan Terbatas, penyertaan modal negara adalah pemisahan kekayaan negara dari APBN atau penetapan cadangan perusahaan atau sumber lain untuk dijadikan sebagai modal BUMN dan/atau perseroan terbatas lainnya dikelola secara korporasi. ${ }^{15}$

\footnotetext{
${ }^{15}$ Rahayu Hartini, "Kepailitan Badan Usaha Milik Negara (BUMN) Persero”, Ringkasan Disertasi, Program Pascasarjana Universitas Airlangga, Surabaya, 2010, hlm. 20.
} 
Selanjutnya Pasal 4 PP No. 44 Tahun 2005 menentukan bahwa setiap penyertaan dari APBN dilaksanakan sesuai ketentuan bidang keuangan negara. Berdasarkan ketentuan Pasal 4 ayat (3) UU No. 19 Tahun 2003, penyertaan dari APBN harus peraturan pemerintah (PP). Untuk penyertaan yang tidak berasal dari APBN menurut Penjelasan Pasal 4 ayat (5) UU No. 19 Tahun 2003 dengan keputusan RUPS atau Menteri Negara BUMN dan dilaporkan kepada Menteri Keuangan. ${ }^{16}$

Penyertaan modal berdasarkan Pasal 5 PP No. 44 Tahun 2005 dapat dilakukan oleh negara antara lain dalam hal pendirian BUMN atau perseroan terbatas. Pendirian Persero merupakan bagian dari penyertaan modal. Sebelum penyertaan modal menjadi modal Persero diperlukan adanya syarat kajian yang mendalam tentang pentingnya penyertaan modal tersebut dilakukan. Kajian ini dilakukan 3 (tiga) menteri yakni Menteri Keuangan, Menteri Negara BUMN, dan Menteri Teknis. Secara rinci prosedur penyertaan tersebut diatur dalam Pasal 10 ayat (1) sampai ayat (4) PP No. 44 Tahun 2005. ${ }^{17}$

Proses berikutnya diatur dalam Pasal 15 PP No. 44 Tahun 2005. Berdasar kajian tersebut, Presiden akan menerbitkan peraturan pemerintah tentang pendirian Persero yang memuat pendirian, maksud dan tujuan, dan jumlah kekayaan yang dipisahkan untuk modal Persero. Jumlah antara penyertaan negara dan modal harus sama. Dalam peraturan pemerintah tersebut juga dimuat bahwa penyertaan modal negara adalah kekayaan negara yang dipisahkan yang berasal dari APBN tahun anggaran tertentu. Berdasar peraturan pemerintah pendirian ini, Menteri Negara BUMN mewakili negara, menghadap notaris untuk memenuhi tata cara pendirian perseroan terbatas. Hal-hal dimuat peraturan pemerintah pendirian akan dimuat dalam anggaran dasar Persero. ${ }^{18}$

Kedudukan Menteri Negara BUMN adalah mewakili negara sebagai pemegang saham. Ini merupakan delegasi dari negara, tetapi menurut Pasal 6 UU No. 19 Tahun 2003 proses peralihan kewenangan tidak langsung dari presiden kepada Menteri Negara BUMN. Pelimpahan tersebut melalui Menteri Keuangan kepada Menteri Negara BUMN dan/atau substitusinya untuk bertindak untuk dan atas nama negara. Pelimpahan ini diatur dalam Pasal 1 PP No. 41 Tahun 2003 tentang Pelimpahan Kedudukan, Tugas dan Kewenangan Menteri Keuangan Pada Perusahaan Perseroan

\footnotetext{
${ }^{16}$ Ibid.

${ }^{17}$ Ibid.

${ }^{18}$ Ibid., hlm. 21.
} 
(Persero), Perusahaan Umum (Perum), dan Perusahaan Jawatan (Perjan) kepada Menteri Negara Badan Usaha Milik Negara. ${ }^{19}$

Setelah proses pemisahan kekayaan negara melalui Peraturan Pemerintah Pendirian Persero selesai dilakukan, pendirian Persero selanjutnya dilakukan melalui hukum privat atau hukum perseroan. Melalui prosedur hukum ini, maka penyertaan negara berubah menjadi modal perseroan yang berwujud saham. Sejak Persero berdiri berdasarkan hukum privat atau hukum perseroan, dianggap mempunyai hak dan kewajiban sendiri yang terlepas dari negara. Tanggal pengesahan pendirian Persero oleh Menteri Hukum dan HAM RI merupakan tanggal pemisahan tanggung jawab antara pemegang saham dan Persero sebagai badan hukum. ${ }^{20}$

Menurut Arifin P. Soeria Atmadja, telah terjadi transformasi hukum publik ke hukum privat ketika terjadi transaksi, maksudnya adalah ketika telah ada akte pendirian PT, maka saat itulah badan ini dikuasai hukum privat yakni hukum perseorangan. Pembuatan akte pada hakikatnya merupakan suatu kontrak, dan dalam kontrak itu merupakan suatu perbuatan privat. ${ }^{21}$

Dari penjelasan di atas secara jelas terlihat Persero adalah PT. Walaupun ada unsur negara di dalam perusahaan tersebut, tetapi oleh karena badan usaha ini adalah PT, maka badan usaha tersebut harus tunduk kepada UU No. 40 Tahun 2007 yang menjadi dasar substantif pengaturan eksistensi PT.

PT oleh hukum dipandang memiliki kedudukan mandiri terlepas dari orang atau badan hukum lain dari orang yang mendirikannya. Walaupun negara yang mendirikan Persero, kedudukan Persero harus terlepas dari kedudukan negara sebagai pendiri Persero tersebut. Di satu pihak PT merupakan wadah yang menghimpun orang-orang yang mengadakan kerjasama dalam PT, tetapi di lain pihak segala perbuatan yang dilakukan dalam rangka kerjasama dalam PT itu oleh hukum dipandang semata-mata sebagai perbuatan badan itu sendiri. Oleh karena itu, segala keuntungan yang diperoleh dipandang sebagai hak dan harta kekayaan badan itu sendiri. Demikian pula sebaliknya, jika terjadi suatu utang atau kerugian dianggap menjadi beban PT sendiri yang dibayarkan dari harta kekayaan PT. ${ }^{22}$
${ }^{19}$ Ibid.
${ }^{20}$ Ibid.
${ }^{21}$ Ibid.
${ }^{22}$ Rudhi Prasetya, Kedudukan Mandiri Perseroan Terbatas Disertai Dengan Ulasan Menurut Undang-Undang No. 1 Tabun 1995, Alumni, Bandung, 1995, hlm. 9. 
Penyetoran modal pada saat pendirian maupun pada saat penambahan modal PT dalam bentuk saham merupakan suatu penyertaan. Suatu penyertaan adalah keikutsertaan seseorang mengambil bagian dalam suatu badan hukum. Penyertaan itu diwujudkan melalui lembaga saham. ${ }^{23}$

Wujud penyertaan itu adalah penyetoran sejumlah nilai nominal saham yang telah ditentukan dalam anggaran dasar. Penyetoran atas saham itu sendiri menurut Pasal 34 ayat (1) UU No. 40 Tahun 2007 dapat berwujud uang atau bentuk lainnya.

Secara yuridis, modal yang disertakan ke dalam perseroan bukan lagi menjadi kekayaan orang yang menyertakan modal, tetapi menjadi kekayaan perseroan itu sendiri. Di sini terjadi pemisahan kekayaan antara kekayaan pemegang saham dan perseroan. Dengan karakteristik yang demikian, tanggung jawab pemegang saham atas kerugian atau utang perseroan juga terbatas. Utang atau kerugian tersebut semata-mata dibayar secukupnya dari harta kekayaan yang tersedia dalam perseroan.

Atas dasar konsep yang demikian itu, maka ketika negara menyertakan modalnya dalam bentuk saham ke dalam Persero dari kekayaan negara yang dipisahkan, demi hukum kekayaan itu menjadi kekayaan Persero. Tidak lagi menjadi kekayaan negara. Konsekuensinya, segala kekayaan yang didapat baik melalui penyertaan negara maupun yang diperoleh dari kegiatan bisnis Persero, demi hukum menjadi kekayaan Persero itu sendiri.

\section{Penutup}

Pertama, Persero identik dengan perseroan terbatas. Hal tersebut disimpulkan dari definisi Persero yang ditentukan UU No. 19 Tahun 2003 dan unsur-unsur yang melekat dalam substansi Persero. Oleh karena itu Persero bukan badan hukum publik, tetapi badan hukum privat yang tunduk kepada hukum privat.

Kedua, kekayaan keseluruhan yang pada Persero adalah milik Persero itu sendiri bukan milik negara. Persero adalah subyek hukum yang memiliki kapasitas harta benda atas nama dirinya sendiri. Kedudukan negara di dalam Persero hanyalah sebagai pemegang saham. Kekayaan keseluruhan Persero bukanlah milik pemegang saham. Kekayaan yang dapat diklaim sebagai kekayaan negara hanyalah sejumlah saham yang dikuasai atau dimiliki negara.

\footnotetext{
${ }^{23}$ Ibid, hlm. 14.
} 


\section{Daftar Pustaka}

Ali, Chidir, Badan Hukum, Alumni, Bandung, 1987.

Cheeseman, Henry R, Business Law: Ethical, International and E-Commerce Environment, Fourth Edition, Prentice Hall, New Jersey, 2001.

Hamilton, Robert W, The Law of Corporation, Minn West Publishing Co, St. Paul, 1996.

Hartini, Rahayu, "Kepailitan Badan Usaha Milik Negara (BUMN) Persero”, Ringkasan Disertasi, Program Pascasarjana Universitas Airlangga, Surabaya, 2010.

Hartono, Sri Rejeki et.al, ed, Permasalahan Seputar Hukum Bisnis: Persembahan kepada Sang Maha Guru, Tanpa Penerbit, Yogyakarta, 2006.

Jager, Ella Gepken et.al, eds, VOC 1602 - 2002: 400 Years of Company Law, Kluwer Legal Publisher, Deventer, 2005.

Kelly, David, et.al, Business Law, Cavendish Publishing Limited, London, 2002.

Khairandy, Ridwan, Pengantar Hukum Dagang, FH UII Press, Yogyakarta, 2006.

Kraakman, Reiner R, et.al, The Anatomy of Corporate Law: A Comparative and Functional Approach, Oxford University Press, Oxford, 2005.

Purwosutjipto, H.M.N, Pengertian Pokok Hukum Dagang Indonesia, Jilid 2, Djambatan, Jakarta, 1982.

Ranuhandoko, I.P.M, Terminologi Hukum Inggris-Indonesia, Sinar Grafika, Jakarta, 2003.

Satrio, J, Hukum Pribadi, Bagian I Persoon Alamiah, Citra Aditya Bakti, Bandung, 1999.

Vermuelen, Erik P.M, The Evolution of Legal Business Forms in Europe and the United States: Venture Capital, Joint Venture, and Partnership Structures, Kluwer Law International, Deventer, 2002. 